for use in the pottery industry, and is an abridgment of a paper previously published in the Journal of Scientific and Industrial Research [India]. The Bulletin is well produced, and provides a good illustration of the change in outlook that is taking place in India at the present time.

\section{Insects and the Diseases of Conifers in New Zealand}

IN "New Zealand Forest Research Notes" (1, No. 8 ; October 1953. Wellington : Government Printer), the forest pathologist, G. B. Rawlings, discusses insects of Pinus radiata forests in New Zealand, giving a list of all the insects known to have any connexion with Pinus radiata forests in the country. $P$. radiata is an introduced exotic species of conifer and has been widely planted. Introduced exotics, whether forest or agricultural, planted as pure crops on a large scale in many parts of the world, have proved to be very subject to attack by fungus or insect pests, some of which are of local origin, and the others introduced. With the presence of extensive pure crops in the countryside, the danger becomes greatly aggravated, and heavy losses may be entailed by the dangerous attempts to provide within short periods rapid-growing crops to supply either an existing demand or to obtain high financial returns. There are countries where the introduction of exotics (New Zealand is an instance) to increase the area of forests in the country is fully justified. 'The Forest Department of New Zealand commenced planting conifer exotics early in the present century. Private companies took up the work, with the result that many large areas of exotic conifers, such as $P$. radiata, for example, exist in pure blocks. Coleoptera and Lepidoptera (for example, Tortrix) may prove exceptionally dangerous, attacks once started spreading with great rapidity and getting the upper hand. An annotated list has been compiled with the main objective of recording all insects known to have any connexion with $P$. radiata forests in New Zealand. As the author writes, it is important for the forest officer to understand at least the rudiments of the life-histories of the insects, because species thought to be unimportant may suddenly become significant under certain conditions. It is not only in Europe where the forest officer has had to face sudden outbreaks of this type; the more dangerous are new countries where forestry conditions are not so well understood, and unknown and untried exotics have been introduced.

Society for the Promotion of Nature Reserves: Handbook for 1954

THE handbook for 1954 of the Society for the Promotion of Nature Reserves (pp. $64+8$ plates; from the Society, c/o British Museum (Natural History), London, 1954; 5s.) includes the annual report and financial statement for the year ended March 31, 1954. The lease of Wood Walton Fen to the Nature Conscrvancy has greatly reduced the Society's outgoings, and its membership has increased. Further, it is no longer necessary to keep in being the many regional investigation committees set up some years ago, some of which have been converted into committees of local natural history societies or trusts. At the annual meeting of the Council on July 1, 1954, the president, Lord Hurcomb, emphasized the ability of the Society to stimulate public interest in, and support for, the Nature Conservancy and said that the Society also endeavours to extend such interest and support to the protection of flora and fauna and scenic beauty elsewhere, in close association with the International Union for the Protection of Nature and the British Co-ordinating Committee for Nature Conservation. The Society is also able and ready to give financial support for the preservation of areas which may not on scientific grounds justify in present circumstances the limited funds of the Nature Conservancy but need and merit protection before they are lost for ever. Specific examples of how this has been done in Lincolnshire are given in a lecture on the Lincolnshire Naturalists' Trust, delivered by Mr. A. E. Smith at the annual meeting of the Society on July 1 and which is published in the handbook. The handbook also includes an illustrated account, by Mr. E. J. Mason, of the island of Steep Holm, in the Bristol Channel, and the Steep Holm Trust; a note by Mr. F. H. W. Green on the progress of the Nature Conservancy in the acquisition and safeguarding of sites of special scientific interest; a note on the Nature Protection Conference at Beirut; and an illustrated account, by Dr. L. Machwa, of experiments which the Lower Austrian Nature Protection authorities have made with propaganda posters on Nature protection.

\section{Exhibition of Historic Astronomical Books}

THE exhibition of historic astronomical books which is currently being held at the Science Museum, London (see Nature, August 14, p. 298), is one of a series designed to illustrate science and technology and their histories by means of the written word or pictorial representation, as distinct from the actual apparatus or products. In addition to those in the Science Museum's own possession, the Royal Astronomical Society has lent many valuable books. The catalogue of the exhibition (Museum Book Exhibition No. 3: Historic Astronomical Books. By G. H. Adams and $H$. R. Calvert. $P p .29$. London: H.M.S.O., 1954. 2s. net) contains the titles of seventyfive books, the first of which is Newton's "Philosophiæ Naturalis Principia Mathematica" (1687) and the last Struve's "Stcllarum Duplicium et Multiplicium Mensuræ Micrometricix" (1837). No books published within the past hundred years have been included, for which reason modern works (such as those of Einstein, Eddington, Jeans and Lockyer) which rank as historic books are not mentioned. When books are published in a language other than English, a short title, sufficient for identification, is first given in the original language, followed by an English translation of some or all of the original title. An alphabetical index of authors appears at the end of the catalogue.

\section{Announcements}

Prof. P. A. M. Dirac, Lucasian professor of mathematics in the University of Cambridge, has been granted leave of absence for the current academic year by the University. Prof. Dirac is now visiting the Tata Institute of Fundamental Research at Bombay, where he is staying until early in 1955, after which he is proceeding via Japan and Van. couver to the United States for a short visit, and then to the National Research Council of Canada at Ottawa.

ERratum. In the article entitled "Differentiation of Growing and Non-growing Bacteria by a Staining Technique" in Nature of November 13, on p. 921, col. 2, line 35, the time of staining should read "30-60 sec.", not "30-60 min." as printed. 